\title{
Economic externalities and urban solid waste in Mexico
}

\section{Externalidades económicas y residuos sólidos urbanos en México}

\author{
TAVERA-CORTÉS, María Elena†๋, JIMÉNEZ-GARCÍA, Martha and MENA-ESPINO, Xenia
}

Instituto Politécnico Nacional-UPIICSA, Mexico.

ID $1^{\text {st }}$ Author: María Elena, Tavera-Cortés / ORC ID: 0000-0002-2179-2735

ID $1^{\text {st }}$ Co-author: Martha, Jiménez-García / ORC ID: 0000-0002-8556-2955

ID $2^{\text {nd }}$ Co-author: Xenia, Mena-Espino / ORC ID: 0000-0002-0248-8770

DOI: $10.35429 / J M P C .2020 .17 .6 .35 .40$

Received January 20, 2020; Accepted June 30, 2020

\begin{abstract}
In the last century, garbage has been considered as an energy resource, on one hand, because when it is deposited in landfills or dumbs it produces biogas with a major component of methane (more than 50\%), methane is considered as a greenhouse gas that has negative impacts on the environment. On the other hand, garbage could be treated in thermochemical processes of incineration or gasification, resulting in energy generation that could be by vapor generation in the case of incineration, or a mixture of gases mainly composed by $\mathrm{CO} 2, \mathrm{H} 2$, and $\mathrm{CH} 4$ by the gasification process; The last two gases could be used to generate vapor as well or used as fuel in internal combustion engines or fuel cells in a near future. The information obtained from the urban solid waste in Mexico is limited concerning to the inventories of generation, on the volume estimation of handling and disposal, according the National Institute of Geography and Statistics (INEGI by the initials in Spanish), from the Municipals Governments National Census until July 2016, Mexico City occupies the first place in recollection of urban solid wastes generating 16 tons daily, the second one is Mexico State with 13 tons, Jalisco with 6.9 tons and Veracruz with 6 tons, on average Mexico generate 42 millions of tons of urban solid waste per year, and only $38 \%$ are organic waste. As a result of the complexity of handling urban solid waste, this paper presents a study in situ of the exploitation of biomass within an organic fraction of urban solid wastes, by means of biogas estimation in a landfill with potential to be exploit in clean energy generation, transforming the negatives externalities because of the disposal of urban solid wastes into positive externalities due to the utilization of the calorific potential from the biomass.
\end{abstract}

Urban Solid Waste, Economic Externalities, Clean Energy Generation

\begin{abstract}
Resumen
En el último siglo, la basura ha sido considerada como un recurso energético, por un lado, porque cuando se deposita en vertederos o mudas produce biogás con un componente mayoritario de metano (más del 50\%), el metano es considerado un gas de efecto invernadero que tiene impactos negativos en el medio ambiente. Por otro lado, la basura podría ser tratada en procesos termoquímicos de incineración o gasificación, dando como resultado una generación de energía que podría ser por generación de vapor en el caso de incineración, o una mezcla de gases compuesta principalmente por $\mathrm{CO} 2, \mathrm{H} 2$ y $\mathrm{CH} 4$ por la gasificación. proceso; Los dos últimos gases también podrían usarse para generar vapor o usarse como combustible en motores de combustión interna o celdas de combustible en un futuro cercano. La información obtenida de los residuos sólidos urbanos en México se limita a los inventarios de generación, sobre la estimación del volumen de manejo y disposición, según el Instituto Nacional de Geografía y Estadística (INEGI), de los Gobiernos Municipales Nacional. Censo hasta julio de 2016, la Ciudad de México ocupa el primer lugar en recolección de residuos sólidos urbanos generando 16 toneladas diarias, el segundo es el Estado de México con 13 toneladas, Jalisco con 6.9 toneladas y Veracruz con 6 toneladas, en promedio México genera 42 millones de toneladas de residuos sólidos urbanos por año, y solo el $38 \%$ son residuos orgánicos. Como resultado de la complejidad del manejo de residuos sólidos urbanos, este trabajo presenta un estudio in situ de la explotación de biomasa dentro de una fracción orgánica de residuos sólidos urbanos, mediante estimación de biogás en un relleno sanitario con potencial de aprovechamiento en generación de energía limpia. transformando las externalidades negativas por la disposición de residuos sólidos urbanos en externalidades positivas por la utilización del potencial calorífico de la biomasa.
\end{abstract}

Residuos Sólidos Urbanos, Externalidades Económicas, Generación de Energía Limpia

Citation: TAVERA-CORTÉS, María Elena, JIMÉNEZ-GARCÍA, Martha and MENA-ESPINO, Xenia. Economic externalities and urban solid waste in Mexico. Journal of Microfinance Planning and Control. 2020. 6-17:35-40.

\footnotetext{
* Correspondence to the Author (Email: mtavera@ipn.mx)

$\dagger$ Researcher contributing as first author.
} 


\section{Introduction}

Economics is a social science that studies scarce goods and with the development of the consumer economy, the volume of urban solid waste (MSW) has increased in the world according to Kaza et al., (2018), solid waste management it has become a global problem and it is the poor who are most affected. Greenhouse gases come from waste and contribute to climate change. In 2016, 5\% of global emissions came from solid waste excluding transportation. The negative externalities due to the generation of 2010 million tons of MSW per year in the world have impacts on the quality of life of the population. However, there is a problem in the management of MSW while middle and high income countries provide almost universal collection services, recovering more than a third of the waste through recycling and composting. In lowincome countries, around $48 \%$ is collected in cities, but only $26 \%$ in rural areas, and $4 \%$ is recycled at the national level, which implies that negative externalities from the emission and management of MSW they are persistent and affect the quality of life of the inhabitants in those countries where Mexico is located.

\section{Conceptual framework}

There are various conceptualizations about the use of urban solid waste. An important approach that arises from the Kyoto protocol is the promotion of Sustainable development, seen as an opportunity to use energies with cleaner means than conventional ones and avoid greenhouse gas emissions Vergara and Ortiz (2016). However, the management of solid waste and its correct disposal is also related to the expansion of urban space. When there is unplanned urban expansion, involving the construction of habitable spaces in unsuitable areas, such as river banks, in irregular areas that are not served by adequate collection services, there is a tendency for uncontrolled waste to damage the subsoil and the waterways, making them a public health risk Maiello et al., (2018). Biogas comprises a mixture of gases that includes methane, carbon dioxide, low amounts of hydrogen, nitrogen, hydrogen, sulfur, and traces of other gases. Biogas is produced by decomposition of organic matter under anaerobic conditions, in conjunction with the generation of energy and new biomass due to the action of the microorganisms Jiménez and Velásquez (2019).
The authors Clavijo and Pillajo in (2019) state that it is from experimentation in several countries of the world that an improved incineration system can process domestic, organic industrial waste and that the energy produced by this incineration can be used in various ways. ways where electricity generation stands out but for these to be profitable, large amounts of waste must be counted on, as well as strict atmospheric gas emission standards. However, negative environmental impact implications can be had if externalities are not evaluated for the use of the incineration method. Gasification is a thermochemical process in which a set of chemical reactions occur in an oxygen-poor environment, resulting in the transformation of a solid into a series of gases that can be used in combustion Herrera and Vega (2018). Gónzales and others in (2019) suggest that the recycling of materials, the use of biogas and the direct incineration of organic waste can be used to produce electricity and is the most valuable alternative to organic waste disposed of in a sanitary landfill.

\section{Procedure for the characterization of urban solid waste (MSW)}

The waste characterization process, understanding as waste those materials whose owner discards and that is in solid, semi-solid, liquid or gaseous state contained in containers and that may be susceptible to receiving treatment or final disposal, in accordance with the provisions of the General Law for the Prevention and Comprehensive Management of Waste, as published in the Official Gazette of the federation, October 20, 2004. Solid urban waste known as garbage is waste generated in homes, businesses or on public roads, and it is constituted by the remains of food, packaging or what results from cleaning in streets and public places which are the responsibility of the municipalities and mayors.

It was carried out in the sanitary landfill (considering that a sanitary landfill is an infrastructure work designed in accordance with the official Mexican standard. NOM-083SEMARNAT-2003) located in Ixtapaluca, as a first stage the sampling was carried out for its transfer to laboratory. 
The sampling was carried out in accordance with the provisions of the NMX-AA15-1985 standard that establishes the quartering method for municipal solid waste and the obtaining of specimens for laboratory analysis. The number of samples per origin was determined by identifying the origin of the sample according to the entry record, in order to carry out an adequate count and a record by sampling, later the transfer unit was placed in the shooting area to proceed with the waste discharge.

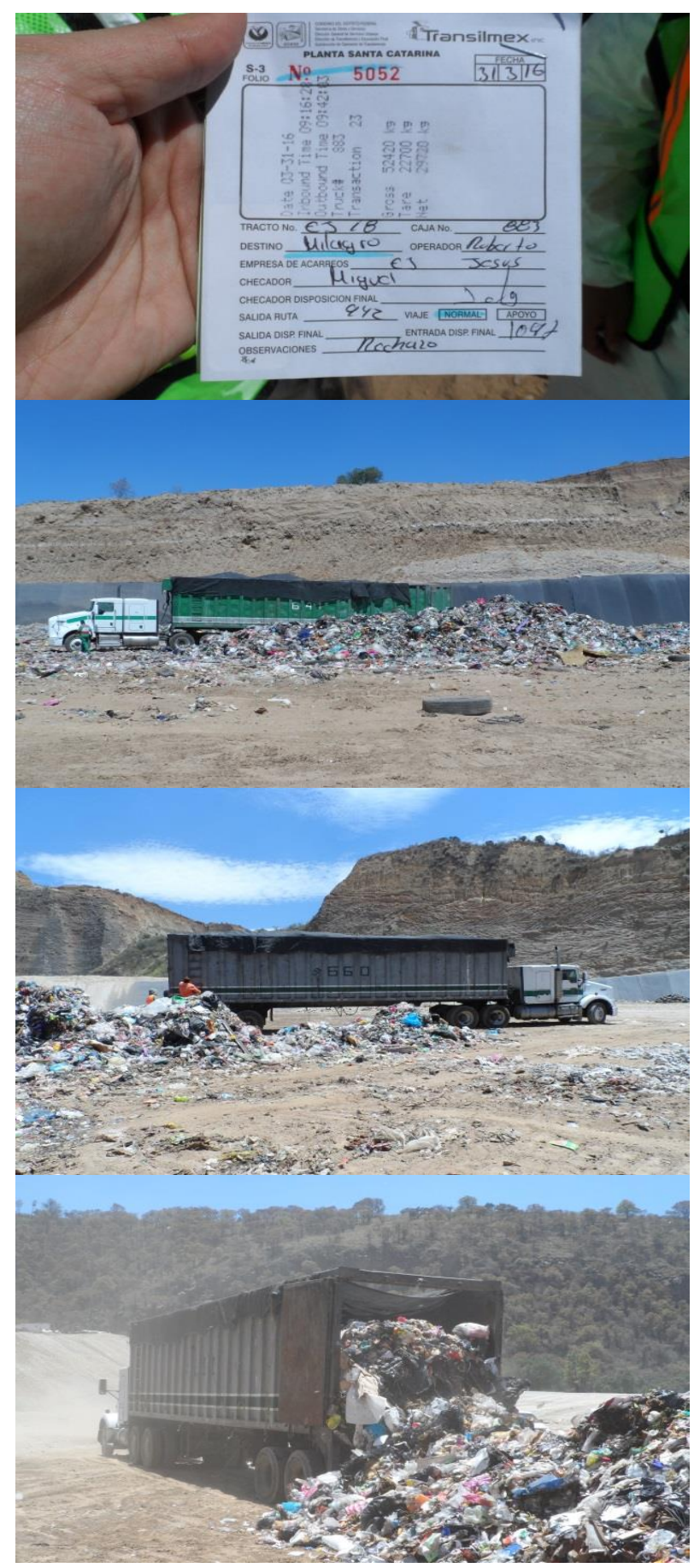

Figure 1 Sample identification

Source: Own elaboration November 2019
As can be seen in Figure 1, the contents of the transfer unit were spread over an area of $4 \times 4$ meters with mechanical equipment, in order to carry out the homogenization procedure and subsequently divide into four approximately equal parts $\mathrm{ABC}$ and $\mathrm{D}$. proceeded to eliminate the opposite parts $\mathrm{A}$ and $\mathrm{C}$ and the operation was repeated until leaving a minimum of $50 \mathrm{Kg}$ of solid waste.

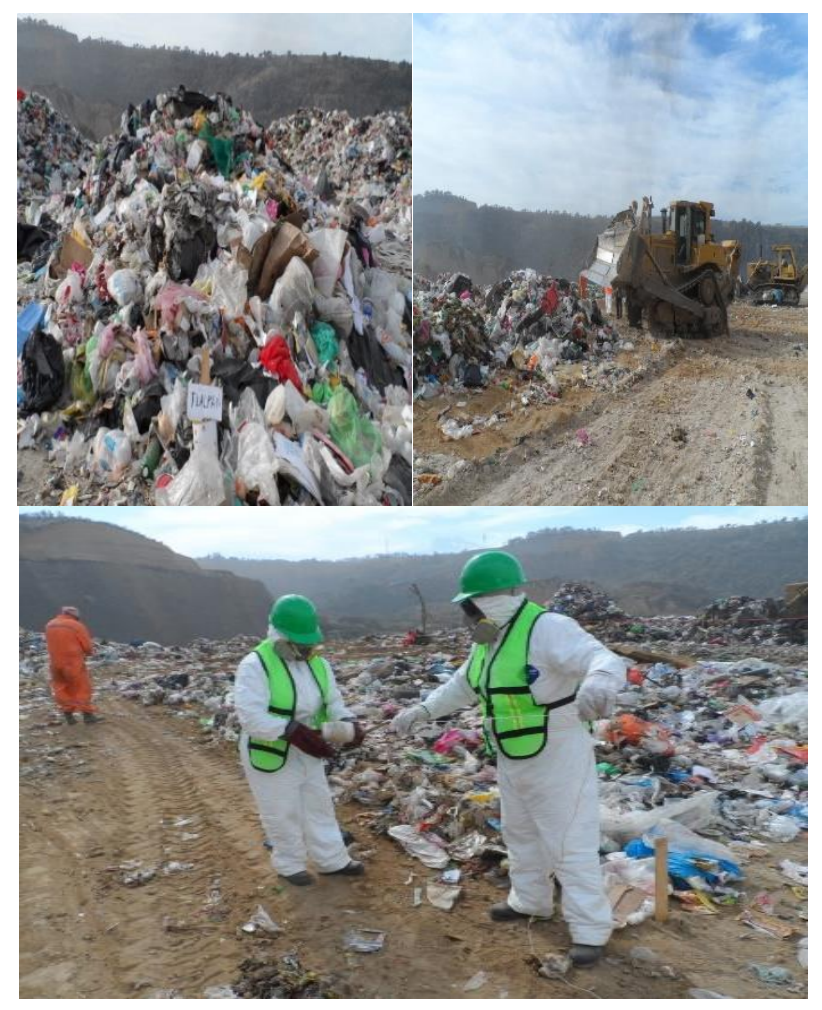

Figure 2 Application of the method of quartering in situ Source: Own elaboration November 2019

As can be seen in Figure 2, the quartering method was implemented, due to the characteristics of the terrain and the space itself where the residues were disposed, the homogenization procedure used for some origins different measures for the selection of sampling areas. by origin of the sample and by number of quarters.

Once the sampling area of $50 \mathrm{~kg}$ was had, the solid waste samples were taken for the physical, chemical and biological analyzes of the laboratory through the selection of by-products, in accordance with the NMX-AA-022 standard. With the rest of the waste, the volumetric weight of the solid waste was determined "in situ", according to the Mexican Standard NMX-AA19. 


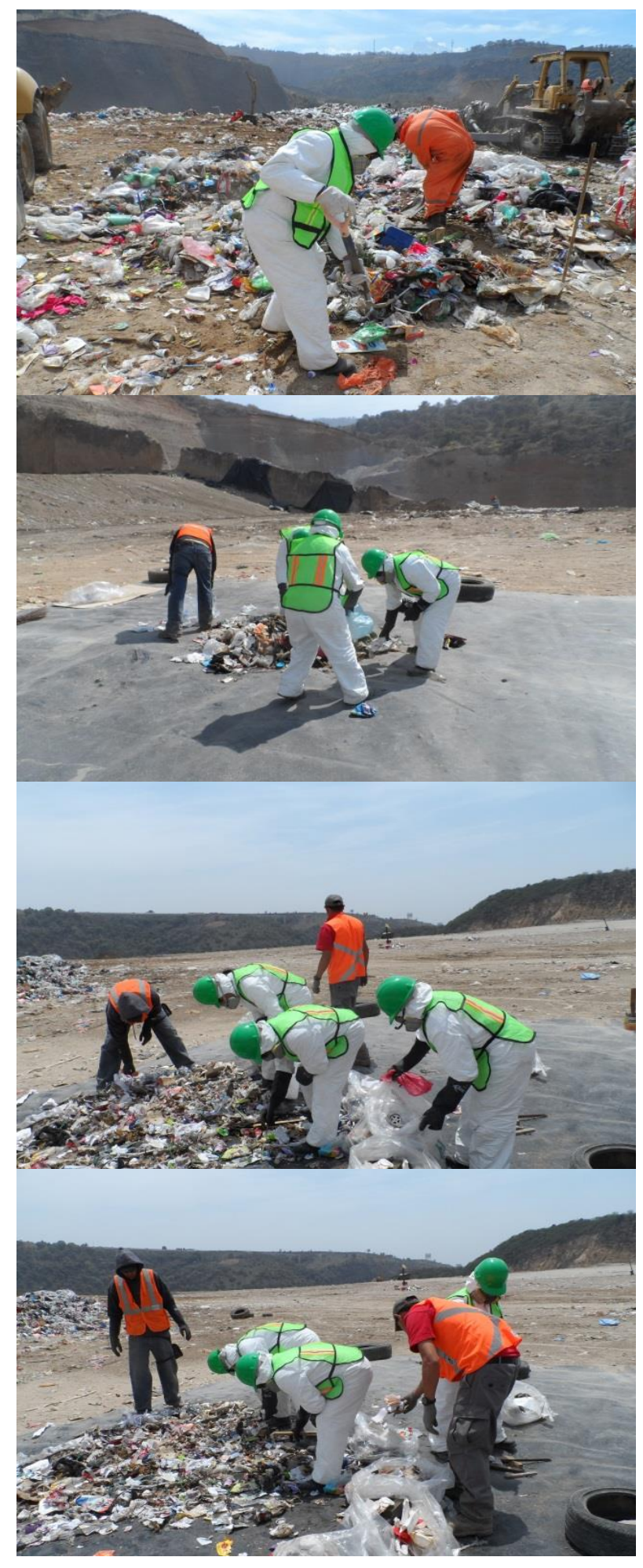

Figure 3 Sampling on site

Source: Own elaboration November 2019.

As shown in Figure 3, the identified byproducts were selected based on the NMX-AA22-1985 standard.

\section{Results of the physical characterization by origin of the waste}

Samples of 13 origins were carried out, as described below in table 1 :

\begin{tabular}{|l|r|r|r|}
\hline \multicolumn{1}{|c}{ By-products } & \multicolumn{1}{c}{$\begin{array}{c}\text { Total } \\
\text { weight in } \\
\text { kilograms }\end{array}$} & $\begin{array}{c}\text { Percentage } \\
\text { ratio }\end{array}$ & $\begin{array}{c}\text { Average } \\
\text { per } \\
\text { 50kg of } \\
\text { sample }\end{array}$ \\
\hline Cotton & 2.442 & 0.38 & 0.188 \\
\hline Paperboard & 41.517 & 6.39 & 3.194 \\
\hline Leather & 12.143 & 1.87 & 0.934 \\
\hline $\begin{array}{l}\text { Fine residue } \\
\text { passing sieve } \\
\text { M 200 }\end{array}$ & 32.055 & 4.93 & 2.466 \\
\hline $\begin{array}{l}\text { Container in } \\
\text { waxed } \\
\text { cardboard }\end{array}$ & 11.739 & 1.81 & 0.903 \\
\hline $\begin{array}{l}\text { Hard vegetable } \\
\text { fiber } \\
\text { (sclerenchyma) }\end{array}$ & 23.829 & 3.67 & 1.833 \\
\hline $\begin{array}{l}\text { Synthetic } \\
\text { fibers }\end{array}$ & 8.518 & 1.31 & 0.655 \\
\hline Bone & 9.728 & 1.50 & 0.748 \\
\hline Rubber & 7.369 & 1.13 & 0.567 \\
\hline Can & 14.462 & 2.22 & 1.112 \\
\hline $\begin{array}{l}\text { Ceramic } \\
\text { earthenware }\end{array}$ & 6.122 & 0.94 & 0.471 \\
\hline wood & 13.108 & 2.02 & 1.008 \\
\hline $\begin{array}{l}\text { Construction } \\
\text { materials }\end{array}$ & 19.623 & 3.02 & 1.509 \\
\hline $\begin{array}{l}\text { Ferrous } \\
\text { material }\end{array}$ & 7.571 & 1.16 & 0.582 \\
\hline $\begin{array}{l}\text { Non-ferrous } \\
\text { material }\end{array}$ & 0.000 & 0.00 & 0.000 \\
\hline Paper & 54.420 & 8.37 & 4.186 \\
\hline $\begin{array}{l}\text { Disposable } \\
\text { diaper }\end{array}$ & 23.701 & 3.65 & 1.823 \\
\hline Film plastic & 52.761 & 8.12 & 4.059 \\
\hline Rigid plastic & 37.963 & 5.84 & 2.920 \\
\hline Polyurethane & 30.893 & 4.75 & 2.376 \\
\hline $\begin{array}{l}\text { Expanded } \\
\text { polystyrene }\end{array}$ & 7.208 & 1.11 & 0.554 \\
\hline Food waste & 73.098 & 11.24 & 5.623 \\
\hline Garden waste & 53.234 & 8.19 & 4.095 \\
\hline Cloth & 46.696 & 7.18 & 3.592 \\
\hline Colored glass & 9.67 & 0.714 \\
\hline Clear glass & 1.061 \\
\hline Other* & & 2.632 \\
\hline & & & \\
\hline
\end{tabular}

Table 1 Average of volumetric weights and proportions for the 13 samples of $50 \mathrm{~kg}$ each

It can be seen in table 1, that the highest proportion of waste is constituted by food waste with $11.24 \%$, followed by paper with $8.37 \%$ while garden waste corresponds to $8.19 \%$ and film plastic is assigned $8.12 \%$ In total, these wastes constitute $37 \%$ of the total physical characterization, which means that it is feasible to use the waste for the generation of biogas and therefore for the generation of electricity.

TAVERA-CORTÉS, María Elena, JIMÉNEZ-GARCÍA, Martha and MENA-ESPINO, Xenia. Economic externalities and urban solid waste in Mexico. Journal of Microfinance Planning and Control. 2020 


\section{Results of chemical characterization in waste}

In order to determine the amount of energy per unit mass / volume of waste that can be released when a chemical oxidation reaction occurs, the calorific potential per selected sample was determined. The calculated calorific value expresses the energy that can be released by the chemical bond between a fuel and the oxidizer (waste). This energy is equal to the energy that held the atoms in the fuel molecules together (binding energy), minus the energy used in the formation of new molecules in matter (generally gases) formed in combustion.

The procedure was carried out by grinding and grinding the waste by selected sample. The residue was reduced in volume in order to have an average of .300 grams, which were treated in calorimeters (LECO AC-600 and LECO AC-350) to obtain the calorific potential. .300 grams per sample was measured, the selected sample quantities were prepared for insertion into the equipment, by removing oxygen:

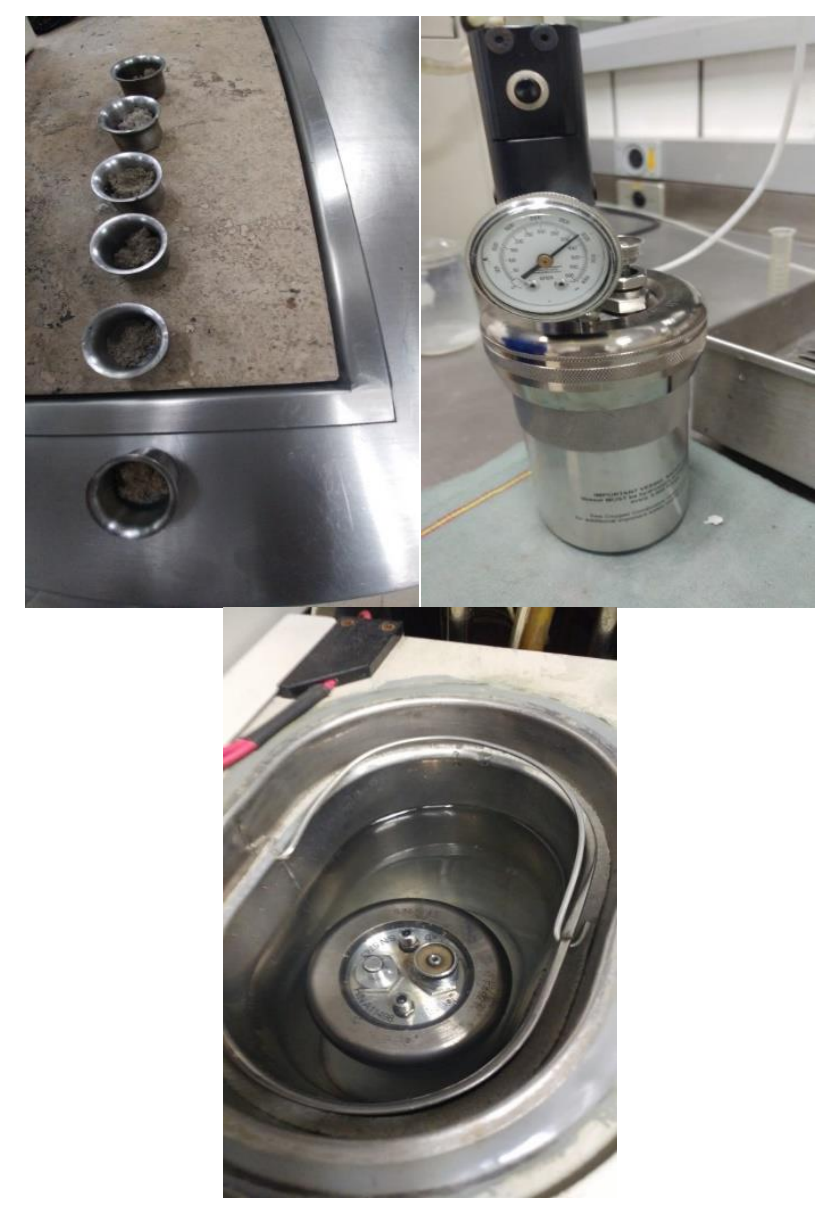

Figure 4 Calorific value measurement procedure in waste Source: Laboratory work November 2019
After the waste was subjected to combustion and the levels of calorific potential generated were monitored, the following results were obtained.

\section{Chemical composition in samples by origin}

The selected samples were analyzed in the first instance to determine the calorific value, $\mathrm{pH}$, the percentage of humidity and the percentage of ash quantity, the results are presented below:

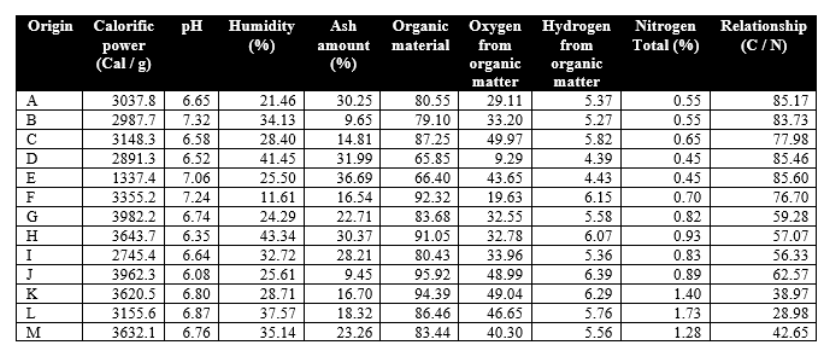

Table 2 Chemical composition in samples by origin

As can be seen in table 2, the average calorific value was located at $3,192.26$ in the selected samples, so that the use of MSW for power generation is profitable and has associated positive externalities due to the commercialization of energy electric.

\section{Conclusions}

As a result of the physical and chemical analysis of the urban solid waste disposed of in the Ixtapaluca landfill, it can be concluded that the negative environmental impact of the disposal of the waste can be transformed into a positive environmental impact by taking advantage of the calorific power of these to be used for the generation and commercialization of electrical energy.

\section{References}

Alves, J. L., Borges, I. B., Ramos, M. A., Nadae, J. D., \& Grangeiro, R. D. R. (2020). Economia circular: O caso dos resíduos da construção civil caririense. Revista Produção Online, 20(2), 449-471. doi:10.14488/1676-1901.v20i2.3825

Clavijo-Ayala, L., y W. Pillajo. «Poder calorífico De La fracción orgánica Biodegradable De Los Residuos sólidos Urbanos Generados En El Sector Sur De La Ciudad De Quito». Gestión Y Ambiente, vol. 22, n. ${ }^{\circ}$, enero de 2019, pp. 19-29, doi:10.15446/ga.v22n1.75473.

TAVERA-CORTÉS, María Elena, JIMÉNEZ-GARCÍA, Martha and MENA-ESPINO, Xenia. Economic externalities and urban solid waste in Mexico. Journal of Microfinance Planning and Control. 2020 
De la Federación, D. O. (1985). Norma de Muestreo-Método de Cuarteo (NMX-AA-151985). México, $D F$.

De la Federación, D. O. (1985). Norma de Selección y Cuantificación de subproductos (NMX-AA-22-1985). México, DF.

De la Federación, D. O. LGPGIR 20 DE octubre de 2004. México, DF.

Del Distrito Federal, G. (2003). Ley de Residuos Sólidos del Distrito Federal. Gaceta Oficial del Distrito Federal, 22, 2-20.

González-Velandia, K., Daza-Rey, D., Caballero-Amado, P., \& Martínez-González, C. (2016). Evaluación de las propiedades físicas y químicas de residuos sólidos orgánicos a emplearse en la elaboración de papel. Revista Luna Azul, 43(43), 499-517. doi:10.17151/luaz.2016.43.21

Kaza, S., Yao, L., Bhada-Tata, P., \& Van Woerden, F. (2018). What a waste 2.0: a global snapshot of solid waste management to 2050. The World Bank.

Maiello, A., Ana Lucia Nogueira de Paiva Britto, \& Valle, T. F. (2018). Implementation of the brazilian national policy for waste management. Revista De Administração Pública (Rio De Janeiro), 52(1), 24. https://doi.org/10.1590/0034-7612155117

NOM-083-SEMARNAT-2003, DOF, 20 de octubre de 2004.

Triana Jiménez, K. M., \& Velasquez, M. E. (2019). Comparison of biogas production obtained from samples of mitú and sibundoy municipal solid waste. Ingeniería $e$ Investigación, 39(2), 31-36. doi:10.15446/ing.investig.v39n2.78597

Vega, L., \& Herrera, A. (2018). Evaluación del potencial energético de la madera residual urbana mediante gasificación. Informador Tecnico, 82(1), 26-40. doi: $10.23850 / 22565035.888$
Vergara Tamayo, C. A., \& Ortiz Motta, D. C. (2016). Contribución al desarrollo sostenible local de los proyectos MDL en el sector de generación eléctrica por biomasa: Caso INCAUCA S.A. Revista De La Facultad De Ciencias Económicas, 24(2), 162-182. doi:10.18359/rfce.2218 